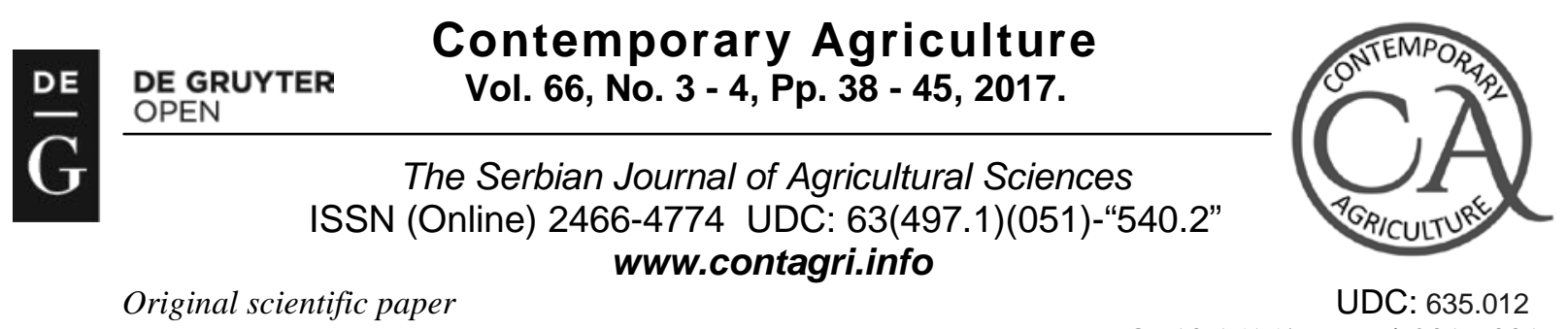

DOI:10.1515/contagri-2017-0017

\title{
OPPORTUNITIES AND BENEFITS OF GREEN BALCONIES AND TERRACES IN URBAN CONDITIONS
}

\author{
Emina MLADENOVIĆ ${ }^{1}$, Milena LAKIĆEVIĆ ${ }^{1}$, Lazar PAVLOVIĆ ${ }^{1}$ \\ Ksenija HIEL ${ }^{1}$, Jelena PADEJČEV ${ }^{1}$
}

\begin{abstract}
Summary: This study tested the hypothesis that a third dimension of urban gardening, in the form of green terraces and balconies, is of immense importance to the public well-being, mitigating climate changes and contributing to a more pleasant life in highly urbanized zones. By means of a concise questionnaire, a total of 82 respondents of different age groups (20-70 years of age) were surveyed about their opinion on green terraces, balconies, and roofs, i.e. the plants and flowers they incorporate. The fieldwork and survey responses facilitated the design of ten different spaces in various conditions. The results obtained enabled the selection of plants which could be used in given conditions, depending on wind, insolation, shade, ground levels, precipitation, etc. A total of three different terraces (out of ten) and three different balconies (out of ten) were enrolled in the study. The research results indicate that ten minutes of gardening could reduce stress levels and restore the positive energy of residents. An increase in the overall plant diversity exerts positive aesthetic and ecological effects. Inner-city areas are often sparsely vegetated, devoid of plants, and densely built-up, thus terraces and balconies have the potential to be retrofitted with suitable greenery.
\end{abstract}

Key words: green balconies, green terraces, urban conditions, flower, green infrastructure

\section{INTRODUCTION}

Urban green spaces are very important for cities, especially the rapidly expanding ones. The world`s cities are becoming increasingly congested and polluted (Wolch et al., 2014). This is a cause for alarm inasmuch as the majority of people live in cities at present. Consequently, changes in the urban environment are taking place as vegetated surfaces are being supplanted by low-albedo materials. These materials are used for constructing highdensity buildings, which are the major cause of increasing temperatures in the urban environment via the urban heat island effect (Razzaghmanesh et al., 2016), alongside the number of residents and the lack of plants and trees. One of the means of mitigating climate change effects is to introduce more greenery into urban areas. It has been proven that green structures are the most effective climate change adaptation tool (Carter, 2011;Berardi et al., 2014; Li et al.,2015;Razzaghmanesh et al., 2016).

Urban greenery encompasses parks, squares, street trees, private gardens, and less conventional spaces for growing greenery such as green roofs, green walls, and community gardens. The latter three are still a novelty in Serbia, and great efforts are expended to realize these structures so that they could become part of urban ecosystem services. Accordingly, not only that the urban heat island effect would be mitigated, but the health conditions of residents would be improved as well (Dahman et al., 2010; Wolch et al., 2014;).

Green spaces contribute to the provision of ecosystem services in urban areas. They filter air, reduce pollution, cool temperatures, attenuate noise, etc. Green roofs have significant cooling effects during the summer and could behave as an insulation layer to keep buildings warmer in the winter (Razzaghmanesh et al., 2016). Moreover, green walls exert similar effects (Rayner et al., 2010), which all stem from the fact that buildings are not directly exposed to the sun and that plant leaves evaporate water during photosynthesis. Greenery increases the aesthetic value of buildings and houses, thus greatly contributing to their worth (Croeser, 2016).

${ }^{1}$ Emina MLADENOVIĆ, PhD, Assistant Professor, Jelena Čukanović, PhD, Assistant Professor, Lazar Pavlović, MSc, Teaching Assistant, Ksenija Hiel, PhD, Assistant Professor, Jelena Padejčev, BSc, student

University of Novi Sad, Faculty of Agriculture, Dositeja Obradovica square 8, 21000 Novi Sad, Serbia

Corresponding author: Lazar Pavlović, e-mail: lazar.pavlovic@polj.uns.ac.rs, tel: +381 214853255 
Many walls, roofs, pavements and public spaces have the necessary physical and climatic characteristics to support plants, but much of this potential is still unrealized. Furthermore, terraces and balconies are yet another potential that is underutilized. In addition to walls and roofs, terraces and balconies represent the third dimension of space greening.

Dense urban areas often have larger areas of vertical space than ground floor areas. Therefore, there is a greater biological potential for vertical greening than horizontal ground-level green space development (Croeser, 2016). Nearly $90 \%$ of city dwellers live in buildings, whereas the remainder still live in houses. This is why the vertical greenery on terraces, balconies, roofs, and walls is so important nowadays.

In a study for the city of Melbourne, Croeser (2016) estimated the biological potential in cities and demonstrated how walls could be used. This study argued a favorable method of quantifying the biological potential in different cities for different types of greening. In addition to the provision of ecosystem services, green spaces affect human well-being. The urban population is more exposed to stress and they are chronically fatigued. It has been proven that green spaces and plants could reduce the negative impact of job stress and blood pressure fluctuation. Moreover, they positively contribute to the psychological and physical health of humans (Brown et al., 2000; Hynes et al., 2004; Lidemann-Matthies et al., 2016). Some scientific studies have shown that work offices with windows opening to natural elements (such as trees) reduced the negative impact of job stress, and offices with physical access to a balcony and greenery were given the highest ratings for restorative qualities (Bengtsson et al., 2013; Nejati et al., 2016).

This paper displays a similar study for terraces and balconies in the city of Novi Sad, Serbia. Novi Sad is a fast growing city with green areas diminishing daily. Therefore, the purpose of this paper is to demonstrate how balconies and terraces can be converted into green oases for residents, rendering them part of the "lungs of the city". There is no similar research for Novi Sad, thus this study represents an endeavor to define balconies and terraces as the "must-have" features of contemporary buildings, with the aim of obtaining a green label. The effects of green balconies and terraces on human well-being, as well as their overall contribution to ecosystem services, remain crucial considerations with regard to growing plants on balconies and terraces.

\section{MATERIAL AND METHODS}

Novi Sad is the second largest city in Serbia and the administrative centre of the Autonomous Province of Vojvodina and the South Bačka District. The area of Novi Sad has been attractive for settlement throughout the history owing to its favorable geographical location. It is situated in the southern part of the Pannonian Plain, on the banks of the Danube, facing the northern slopes of the mountain of Fruška Gora $\left(45^{\circ} 15^{\prime} \mathrm{N} 19^{\circ} 51^{\prime} \mathrm{E}\right)$. The blooming population growth in the city was recorded during the post-World War II period (1961-1971). This increase was primarily caused by human migration rather than by a natural growth. In the 1990s and 2000s, the city experienced a significant population growth, which resulted in establishing new settlements with high-density buildings. The city growth has been accompanied by an increase in temperature.

Novi Sad has a temperate continental climate with four seasons. The average temperature through the year is $11.8^{\circ} \mathrm{C}$, the relative humidity is $71 \%$, the average precipitation is $647.3 \mathrm{~mm}$, and the total sunshine hours per year are 2.135,3. Within the period $2000-2015$, the temperature increased by $2-3^{\circ} \mathrm{C}$, with an average of $24.6^{\circ} \mathrm{C}$ in July and a peak of $41.6^{\circ} \mathrm{C}$.

During this urbanization process, high-rise buildings and collective living replaced individual habitations in almost all major areas of the city of Novi Sad. At present, it is estimated that $90 \%$ of inhabitants live in buildings. Almost all apartments in the buildings have access to terraces or balconies, and these small spaces represent the perfect place for residents to grow their own plants. Many people do not have access to parks and other forms of urban greenery, or they simply do not have time to visit and enjoy them. Growing plants on terraces and balconies can provide small green oases for residents to rest and enjoy after a day's work (Fig. 1 and 2).

A total of ten different terraces and ten different balconies were enrolled in the survey conducted. They were all sorted by different categories encompassing location, insolation, shape, dimension, etc. The example terraces and balconies are all located in different parts of Novi Sad, and their shape, size, and orientation (N, W, E, S) were taken into account (Fig.4). These factors are crucial for the selection of balcony and terrace plants. Out of the initial ten terraces, a total of three (a house terrace, a roof terrace and a building terrace) were selected for the purpose of this paper. Furthermore, out of the initial ten balconies, the balconies in the shape of a triangle, rectangle, and square were ultimately selected. A brief survey was also conducted in order to investigate the commonly used flower species, people's awareness of greenery benefits, and people's opinion on the present state of city greenery. A total of 82 respondents of different age groups (20-70 years of age) were surveyed about their opinion on green terraces, balconies, and roofs, i.e. the plants and flowers they incorporate. Many studies have already reported (Akpinar, 2016; 
Nejati et al., 2016; Urlich et al., 1991; Van den Berg et al., 2010; Wolch et al., 2014; Kaplan et al., 2003) that greenery can have positive effects on the human mood, which is consistent with the results of this survey.

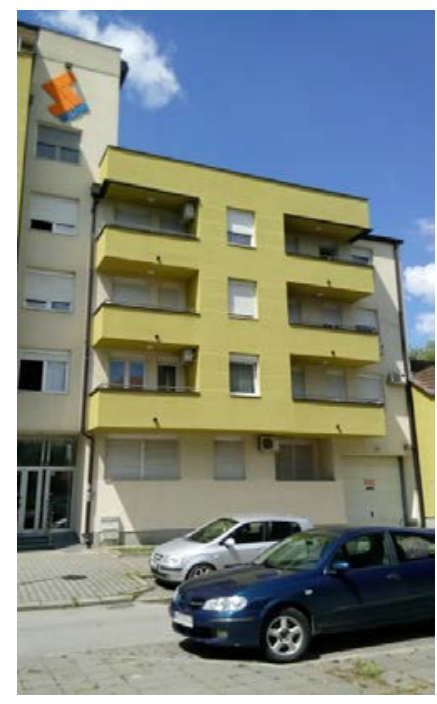

Figure 1. An example of bare balconies devoid of greenery

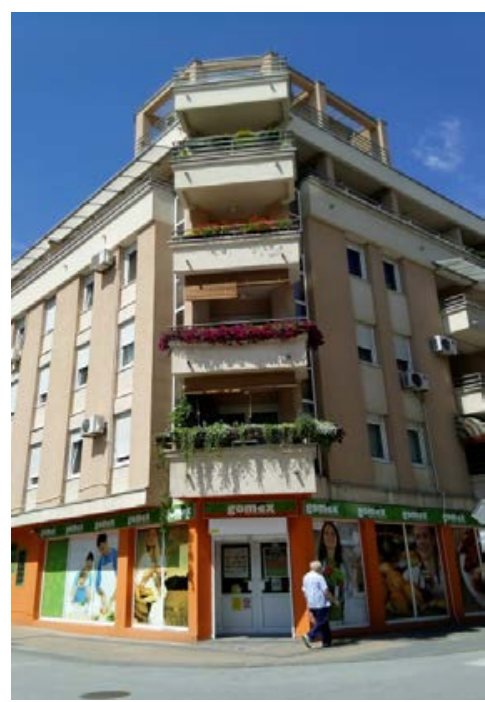

Figure 2. A corner building with balcony greenery increasing its aesthetic value

Almost all flower species, some trees, shrubs, and climbers can be grown on terraces and balconies. Their selection depends mainly on the planting location climate, insolation, and wind. During the design of these spaces, the following factors were taken into account: the appearance and design of spaces, the height (floor) of terraces and balconies and floor-specific climate conditions, and the meticulous selection of plants for every balcony and terrace with plant-specific pots and compost types.

The terrace and balcony spaces were designed to be functional, incorporating the space for garden furniture and plants. The pots and compost types were selected by weight.

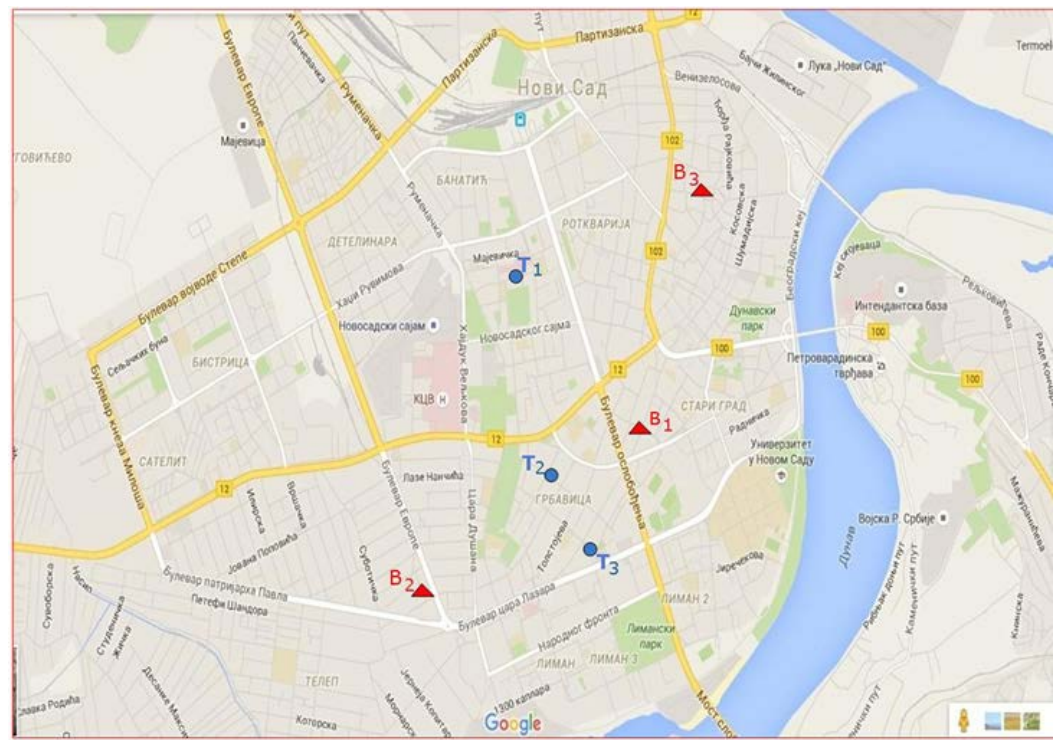

Figure 3. The locations of terraces and balconies in urban parts of the city selected for this study. The terraces are marked with T1, T2, and T3, whereas the balconies with B1, B2, and B3.

They were required to be lightweight because terraces and balconies are not made to support heavy weight. The selected pots are made of clay and plastic with drain holes at the bottom. Three compost types were chosen for the 
plants: loam-based, loam-less, and cacti. The use of each compost type was based on the exposure of plants and flowers to the sun or shade.

With regard to the planting locations, the terraces and balconies in urban parts of the city were selected (Fig. 3). They are all of different shapes, sizes, and expositions.

\section{RESULTS AND DISCUSSION}

\section{Design of the Spaces Studied}

According to the research, the following flowers are the most prevalent: Pelargonium sp. (32\%), Petunia sp., Surfinia sp. (15\%) and Begonia sp. (9\%), while the remainder of species are shown in the diagram below (Diagram 1).

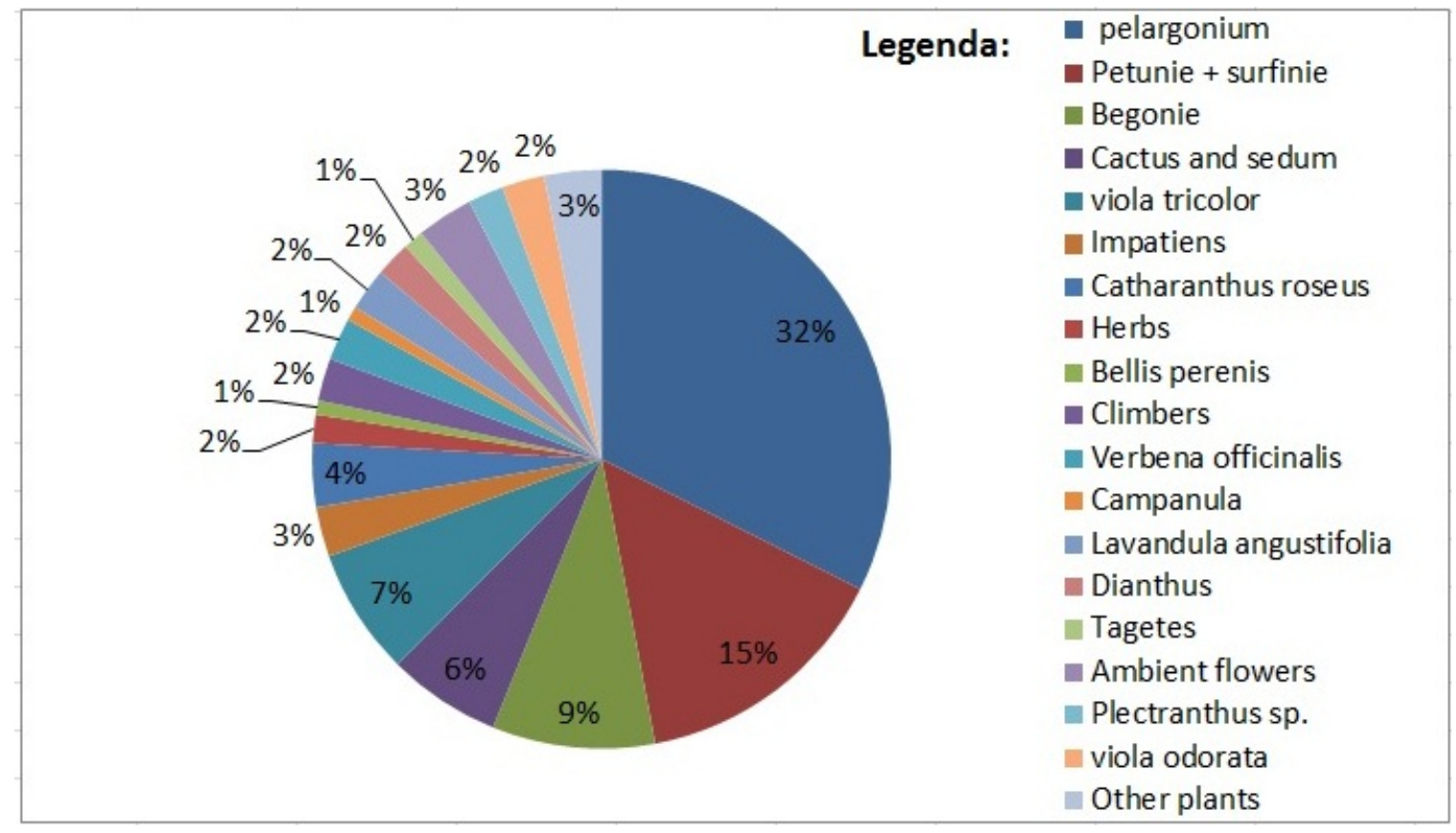

Diagram 1. The list and representation of flower species on the terraces and balconies in the city of Novi Sad according to the respondents.

Although plants ought to be selected on the basis of their growth requirements, the survey indicates that $54 \%$ of respondents buy flowers to their own liking. Only 36\% of respondents emphasize plant growth requirements and cultivation conditions.

As shown in Figure 4, all the terraces and balconies selected are located in different central parts of the city. The house terrace (T1) is located in a single-family residential area. It occupies an area of $8.5 \mathrm{~m} 2$ and faces north, which means that this is a terrace in the shade. It is elevated from the ground by $50 \mathrm{~cm}$ and surrounded by neighboring houses and buildings, thus it is not exposed to strong wind, noise, and harmful air pollutants. The following shadetolerant species were selected for this terrace: busy Lizzie (Impatiens walleriana 'Hook.f.'), African lilly (Agapanthus africanus 'L. Hoffmanns'), bird's nest 'Sansevieria' (Sansevieria trifasciata 'Hahnii'), heartleaf philodendron (Philodendron scandens synonym: P.hederaceum 'Schott'), primrose (Primula vulgaris 'Huds'.), lilly of the valley (Convallaria majalis L.), tuberous begonias (Begonia $\mathrm{x}$ tuberhybrida multiflora 'pink'), azalea rhododendron (Rhododendron indicum L. 'Sweet'). Solar receptivity is an important factor for the arboreal and plant establishment. Most plants (86.4\%) do well on unshaded surfaces and only $4.1 \%$ on moderately or heavily shaded locations (Jim et.al., 2011).

The second terrace studied (T2) is also in the shade. It faces east and it is located in a narrow, densely built street with high buildings eclipsing the sun. It was very important for the space to be functional, because of a small area (3.42m2), but still equipped with all necessary elements. The following plants were used in this instance: Coleus, Ipomea batats 'Margarita', Vinca minor 'Alba', and many others. 

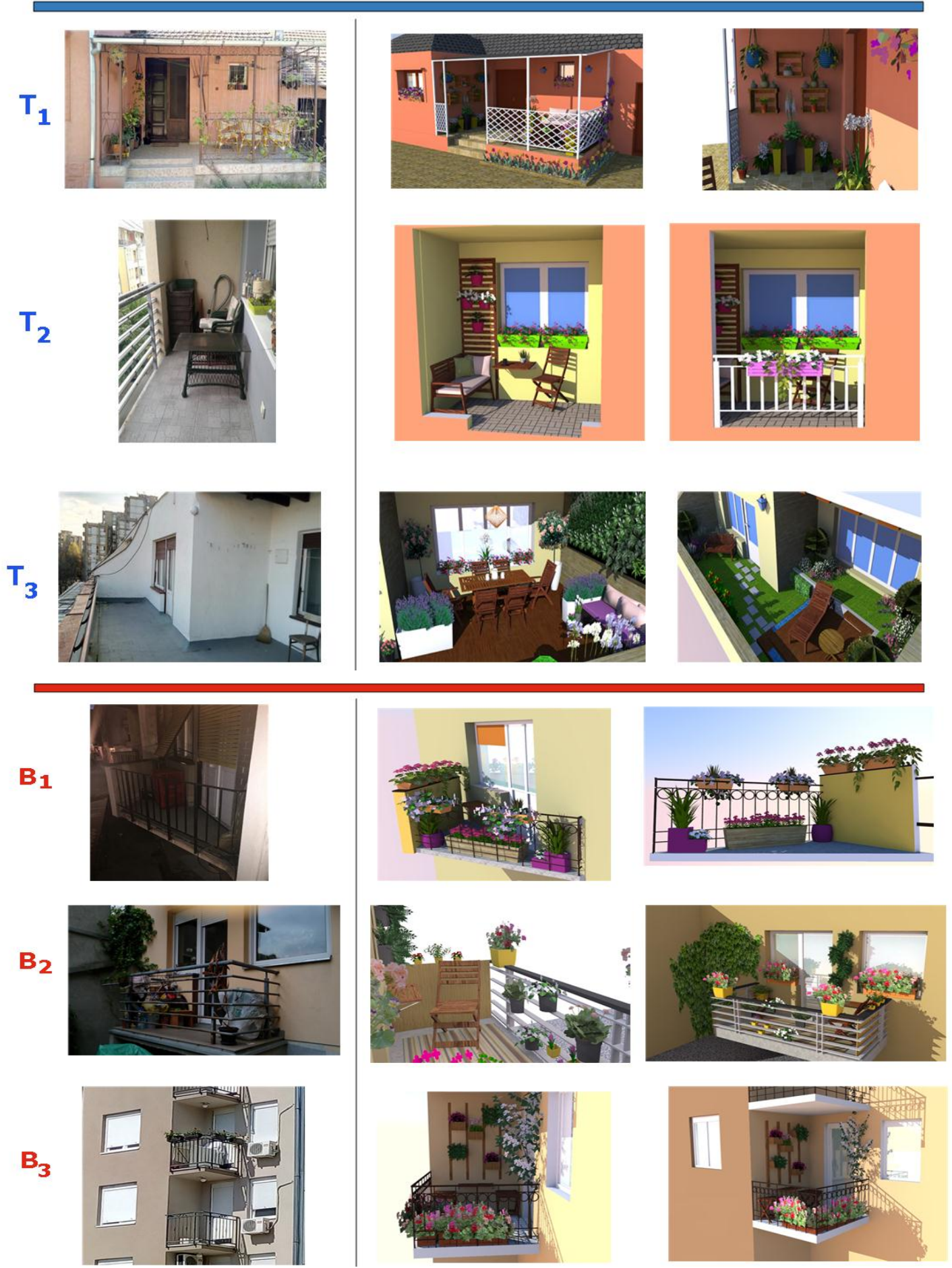

Figure 4: The examples of the terraces $\left(T_{1}, T_{2}\right.$, and $\left.T_{3}\right)$ and balconies $\left(B_{1}, B_{2}\right.$, and $\left.B_{3}\right)$ selected. The present conditions are shown on the left, whereas the new designs with greenery are shown on the right.

The third terrace (T3) is a fourth-floor roof terrace, facing south and covering an area of $30 \mathrm{~m} 2$. Figure 4 displays two different designs of this space. One is an urban and modern garden terrace with potted plants and a big gathering space, whereas the other is a roof garden with lawn grass, decorative trees, shrubs, and shallow-rooting flowers highly tolerant to insolation and wind. The first balcony (B1) is a triangle-shaped balcony also facing south. It 
occupies a small area of $1.7 \mathrm{~m} 2$, which is completely utilized for potted flowers. The second balcony (B2) is mostly sunny during the day. It is in the shape of a rectangle, located on the ground floor, facing east, and occupying an area of $3.6 \mathrm{~m} 2$. The following plant species were used for these sunny terraces and balconies: Clematis florida 'Sieboldi', Surfinia, Tulipa, Lavandula angustifolia, Rosa 'Šarl Aznavur', Tanacetum parthenium, Achilea millefolium 'Kirschkonigin', Stachus byzantina, Pelargonium sp.

The third balcony (B3) faces west and thus the combined plant species for shaded and unshaded surfaces were used.

All the designs are accompanied by straightforward constructions and adequate furniture. The vertical and horizontal spaces were used, as well as the fences, for hanging and placing potted plants. The flower combinations consist of annual, biannual, and perennial flowers, therefore all the terraces and balconies are green and blooming from early spring to the last sunny days in autumn.

\section{Effects of Terrace and Balcony Greenery on Residents}

There are many studies on the effect of parks on the human psychological well-being (Ernston, 2012), stress reducing, mental health, and physical activity (Barton et al, 2010; Ulrich, 1981, 1991; Kaplan and Kaplan, 2003; Wolch et al., 2014). In a major study of Van den Berg et al. (2010), the authors showed that respondents who lived in the vicinity of green spaces were less affected by stressful life events in comparison with those who had low access to green spaces, suggesting that green spaces buffer stress. Due to a high demand for residential and commercial areas, as well as the exponential population growth, the strongest pressure on green spaces is found in the rapidly urbanizing areas (McDonald, 2009; Fanan et al., 2011; Schetke et al., 2016). In the research of Urlich et al. (1983), the Stress Reduction Theory was developed emphasizing the reduction of stress through a person's interaction with nature. The aforementioned theories were confirmed in this study and in many other studies regarding the relationship between the natural environment and human health. It has been proven that daily gardening induces a feeling of comfort, reduces the level of work stress, and helps the healing process. Refocusing on small-scale interventions in urban areas, such as the greening of terraces and balconies, could be one of the solutions for the city residents and climate.

The majority of respondents in this study confirmed access to a balcony or terrace (92.9\%), and all of them (100\%) agreed that greenery exerts positive effects on them.

Urban gardening is very diverse. It encompasses several unique gardening concepts, including container gardening, roof gardening, and community gardening (using outdoor private spaces to cultivate gardens for food and pleasure) (Lindermann - Matthies et al., 2016; Miller, 2008).

Green balconies and terraces provide small spaces where residents can relax by regular, everyday gardening (watering, removing dried leaves and flowers, etc.). Gardening involves all the senses as gardeners smell and touch flowers while performing a series of simple mechanical activities, which relax them and reduce the level of stress. As a result, they can sit and enjoy in their own comfortable green zone. Colors also have positive effects on people. It is well known that, in addition to other warm colors, green has a soothing effect. Therefore, plants and flowers are used to beautify gray walls and cold metal fences. Colorful plants are a typical feature of the modern urban environment and have been found to increase the attractiveness of green spaces in urban settings (Lindermann - Matthies et al., 2016). Only windows opening to natural elements such as flowers and trees reduce the negative impact of stress. However, the access to green balconies or terraces gardened by residents contributes even more to reducing stress, increasing the level of satisfaction and recharging positive energy. In the study of Nejati et al. (2016), the rooms with physical access to a balcony were given the highest ratings for restorative qualities.

\section{Contribution to the Ecosystem}

Balcony and terrace plants could be very effective in buffering noise, collecting dust from the surrounding streets, preserving heat or making shade (provided the space is exposed to high insolation during the summer), and cooling buildings. All these factors result in pleasant surroundings and an increased aesthetic value of the neighborhood. The diversity of plants and flowers exerts positive ecological and aesthetic effects. Moreover, these plants are included in the production of oxygen through photosynthesis and evaporation. In like manner, terrace and balcony greenery is included in the urban ecosystem and facilitates mitigating the heat island effect. It would be too much to think that every terrace or balcony will be green, but provided one in two is, the city would be green enough to decelerate climate changes.

\section{CONCLUSION}

Site conditions and green spaces are of immense importance to the rapidly expanding cities. In densely populated urban neighborhoods, green spaces are diminishing daily due to a high demand for residential and commercial areas, 
as well as the exponential population growth. Infrastructure problems and environmental stressors (such as air pollution and diseases) will increase the demand for urban green spaces and healthy living conditions (Schetke et al., 2016). There are increasing pressures on open spaces and brownfield sites to be utilized for constructing skyscrapers with a great number of apartments. However, apartment balconies and terraces have the potential for growing various kinds of greenery. This study showed that almost all plants could be grown on terraces and balconies provided they are selected in accordance with climate conditions. Consequently, the diversity of plants can have positive effects on climate changes and the urban heat island effect. Climate changes and the urban heat island effect are the greatest challenges facing the world today, and they require new solutions. Green balconies and terraces are one of such solutions, offering a wide range of benefits.

One of the purposes of this study is to identify terraces and balconies as urban gardens. Urban gardening is very diverse. It encompasses several unique gardening concepts, including container gardening, roof gardening, and community gardening (using outdoor private spaces to cultivate gardens for food and pleasure (Lindermann Matthies et. al., 2016; Miller, 2008). Although this concept of gardening is still a novelty in Serbia, there is considerable interest in such innovations in the market. Therefore, vertical greening is hereby promoted in the form of green terraces and balconies with the aim of highlighting their importance to modern sustainably constructed buildings. What is nowadays considered a viable solution, in 10 or even 5 years will be a standard. That is why the innovations in vertical greening on buildings have to be repeatedly encouraged.

\section{ACKNOWLEDGMENT}

This paper is a result of the project of the Ministry of Science, Education and Technological Development of the Republic of Serbia no. III43007, "Research of Climate Change and Their Impact on the Environment: Monitoring the Impact, Adaptation and Mitigation", and the ++project number TR36042, "Optimization of Architectural and Urban Planning and Design in Function of Sustainable Development in Serbia”.

\section{REFERENCES}

AKPINAR, A.: How is high school greenness related to students’ restoration and health?. Urban Forestry \& Urban Greening, 16, 1-8, 2016.

BERARDI, U., GHAFFARIANHOSEINI, A.H., GHAFFARIANHOSEINI, A.: State-of-the-art analysis of the environmental benefits of green roofs. Appl. Energy, 115, 411-428, 2014.

BENGTSSON, A., CARLSSON, G.: Outdoor environments at three nursing homes-qualitative interviews with residents and next of kin. Urban Forestry \& Urban Greening, 12, 393-400, 2013.

BROWN, K.H., JAMETON, A.L.: Public health implications of urban agriculture. J. Public Health Policy 21, $20-39,2000$.

BARTON, J., PRETTY, J.: What is the best dose of nature and green exerciseforimproving mental health? A multi-study analysis. Environmental Science and Technology, 44(10), 3947-3955, 2010.

CROESER, T.: Biological potential in cities: an estimate from Melbourne. Urban Forestry \& Urban Greening, 16, 84-94, 2016.

CARTER, J.G.: Climate change adaptation in European cities. Current Opinion in Environmental Sustainability, 3, 193-198, 2011.

DAHMANN, N., WOLCH, J., JOASSART-MARCELLI, P., REYNOLDS, K., JERRETT, M.: The active city? Disparities in provision of urban public recreation resources. Health and Place, 16(3), 431-445, 2010.

ERNSTSON, H.: The social production of ecosystem services: A frame work for studying environmental justice and ecological complexity in urbanized landscapes. Landscape And Urban Planning,109(1),7-17, 2012.

FANAN, U., DLAMA, K.I., OLUSEYI, I.O.: Urban expansion and vegetal cover loss in and around Nigeria’s Federal Capital City.J. Ecol. Nat. Environ. 3, 1-10, 2011.

HYNES, H.P., HOWE, G.: Urban horticulture in the contemporary United States: personal and community benefits. Int. Conf. Urban Hortic., 643, 171-181, 2004.

KAPLAN, S., KAPLAN, R.: Health, supportive environments, and the reason able person model. American Journal of Public Health, 93(9), 1484-1489, 2003.

LI, X., ZHANG, C., LI, W.,KUZOVKINA,Y. A., WEINER, D.: Who lives in greener neighborhoods? The distribution of street greenery and its association with residents' socioeconomic conditions in Hartford, Connecticut, USA.Urban Forestry \& Urban Greening, 14, 751-759, 2015.

LINDEMANN-MATTHIES, P., BRIEGER, H.: Does urban gardening increase aesthetic quality of urban areas? A case study from Germany. Urban Forestry \& Urban Greening, 17, 33-41, 2016.

MILLER, J.R.: Conserving biodiversity in metropolitan landscapes.A matter of scale (but which scale?). Landscape Journal, 27, $1-8,2008$.

MCDONALD, R.I.: Ecosystem service demand and supply along the urban-to-rural gradient. J. Conserv. Plan. 5, 1-14, 2009.

NEJATI, A., RODIEK, S., SHEPLEY, M.: Using visual simulation to evaluate restorative qualities of access to nature in hospital staff break areas. Landscape and Urban Planning, 148, 132-138, 2016. 
RAZZAGHMANESH, M., BEECHAM, S., SALEMI, T.: The role of green roofs in mitigating Urban Heat Island effects in the metropolitan area of Adelaide, South Australia. Urban Forestry \& Urban Greening, 15, 89-102, 2016.

RAYNER, J.P., FARRELL, C., RAYNOR, K.J., MURPHY, S.M., WILLIAMS, S.G.N.: Plant establishment on a green roof under extreme hot and dry conditions: The importance of leaf succulence in plant selection. Urban Forestry \& Urban Greening, 15, 6-14, 2016.

SCHETKE, S., QURESHI, S.,LAUTENBACH, S., KABISCH, N.: What determines the use of urban green spaces in highly urbanized areas?-Examples from two fast growing Asian cities.Urban Forestry \& Urban Greening, 16, 150-159, 2016.

ULRICH, R. S.: Natural versus urban scenes some psycho-physiological effects. Environment and Behavior, 13(5), 523-556, 1981.

ULRICH, R. S., SIMONS, R. F., LOSITO, B. D., FIORITO, E., MILES, M. A., ZELSON, M.: Stress recovery during exposure to natural and urban environments. Journal of Environmental Psychology, 11(3), 201-230, 1991.

VAN DEN BERG, A. E., MAAS, J., VERHEIJ, R. A., GROENEWEGEN, P. R.: Green space as a buffer between stressful life events and health. Social Science and Medicine, 70(8), 1203-1210, 2010.

WOLCH, J. R., BYRNE, J., NEWELL, J.P.: Urban green space, public health, and environmental justice: The challenge of making cities ‘just green enough’. Landscape and Urban Planning, 125, 234-244, 2014.

Received / Primljen: 10.07.2017.

Accepted / Prihvaćen: 24.12.2017. 